\title{
Coronavirus Disease (Covid-19), is Global Recession Evitable?
}

\author{
Bilkisu Maijamaa ${ }^{1}$, N.O Nweze ${ }^{2}$, Hauwa Daniyan Bagudu ${ }^{3}$ \\ ${ }^{1,2,3}$ Nasarawa State University Keffi \\ maijamaab@nsuk.edu.ng
}

\begin{tabular}{ll}
\hline ARTICLEDETAILS \\
\hline History \\
Received $\quad$ February \\
RevisedFormat $:$ March \\
Accepted : April \\
\hline
\end{tabular}

Keywords :

Covid-19, recession, economy

\begin{abstract}
S
COVID-19 (Coronavirus Disease-2019) is regarded as a public health emergency of international concern. Patients contracting the severe form of the disease constitute approximately $15 \%$ of the cases [WHO). The covid19 is affecting 203 countries and territories around the world. An epidemiological threat such as COVID-19 can have destructive effect on the economy.it is of great importance not to focus only on the epidemiological profile of the virus but also its impact on the economy. As much as economists think about risk-taking as a key driver of the economy, an economy only works if risks are largely known. With the impact of the covid-19 on travel services, durable expenditure, on supply chain and on social isolation (high skilled working from home, home schooling) and impact on demand and supply. On the bases of the listed impact on the economy global recession seems inevitable, there is also possibility of emerging markets. The overall demand effect is probably higher than the initial supply shock. There will be uncertainties, panic, a lot of panic buying and lock-down policies is a key to drive large drop in demand. The investment in a lot of firms especially the small and young firms, spending for households such as rent and mortgagor's depend largely on cash flow. Large drop in demand will lead to force closure in a lot of firms and this will lead to an increase in lay-offs and hence further drop in consumption, and sadly the economy leads to depressing loop.
\end{abstract}

(C2020 STIM Lasharan Jaya Makassar

\section{INTRODUCTION}

Severe acute respiratory syndrome coronavirus 2 (SARS-CoV-2), is a disease Coronavirus disease 2019 (COVID-19). It originated from wet animal market in Wuhan, China, early Dec 2019. There are other similar pandemics such as SARS-CoV-1, which affected 8,000 people in 2002/03, there si $96 \%$ match between bat coronavirus and human found in a study from February it is suggested that the link to humans is not direct but through intermediate host. The corona virus is regarded as a pandemic (World Health Organization. 2020).

The World Health Organization declared the corona virus on $11^{\text {th }}$ of March. WHO defined "A pandemic is the worldwide spread of a new disease, an influenza pandemic occurs when a new influenza virus emerges and spreads around the world, and most people do not have immunity." While US CDC defined "Pandemic refers to an epidemic that has spread over several countries or continents, usually affecting a large number of people." Its declaration is about geographic spread, not about the severity of the disease or virus. There are a lot of outbreak in the past that were regarded as pandemic.

In the $14^{\text {th }}$ century Europe had bubonic plague, 1918-1920 Worldwide Influenza epidemic with over 50 million, 1981- till date HIV-AIDS greater than 25 million lives and 33 million living 
with HIV. Recently there incidences of smaller outbreaks: 2002-04 SARS with 8 thousand cases 774 death, 2009 Avian flu which has claimed 151-575 thousand deaths, 2014-2016 Ebola outbreak with greater than 11 thousand deaths as reported by Novel Coronavirus (2019nCoV) Situation Report-7 - World Health Organization (WHO), January 27, 2020

Richard Baldwin, 2020 on assessing the possible impact of corona virus on the economy, it is of great importance not to focus only on the epidemiological profile of the virus but also its impact on the economy. As much as economists think about risk-taking as a key driver of the economy, an economy only works if risks are largely known. But unknown risks, or uncertainties, can have a larger, more paralyzing effect. That issue of credibility has only become more challenging during this crisis and it makes assessing the impact of the virus on the global economy that much more difficult.

Economical risk the virus exposes a lot of countries especially the developing countries mostly Africa, south Asia and some part of Latin America. This regions have lower health system capacity that is fewer intensive units as well as ventilators. Less possibility to wash their hands with soap frequently because of limited supply of pip born water. This countries are more exposed to the world trade cycle because their demand for goods and services are highly dependent on developed economy demand and hence more vulnerable to the crisis. Far less access to internet services and therefor working from home will have high rate of disruptions and unprecedented economic cost than the already high and heterogeneous cost compared to the developed countries (Richard Baldwin 2020)

Most economist in US and Europe predict major recession. Even if the mortality rate of COVID-19 proves to be less as compared to the number of flu death in other pandemics it is likely to cause major recession (Baldwin, R \& B Weder di Mauro, 2020).Europeans have greater views than the US as shown in table 1.1

Table 1.1 Top Economist Views

\begin{tabular}{|c|c|c|c|}
\hline No & Views & $\begin{array}{l}\text { European panel } \\
\text { views }\end{array}$ & $\begin{array}{l}\text { US } \\
\text { panel } \\
\text { views }\end{array}$ \\
\hline 1 & $\begin{array}{l}\text { Strongly } \\
\text { agree }\end{array}$ & $48 \%$ & $18 \%$ \\
\hline 2 & Agree & $43 \%$ & $44 \%$ \\
\hline 3 & Uncertain & $13 \%$ & $31 \%$ \\
\hline 4 & Disagree & $4 \%$ & $8 \%$ \\
\hline 5 & $\begin{array}{l}\text { Strongly } \\
\text { disagree }\end{array}$ & $0 \%$ & $0 \%$ \\
\hline
\end{tabular}

With the impact of the covid-19 on the economy there will be impact on travel services, durable expenditure, on supply chain and on social isolation (high skilled working from home, home schooling) and impact on demand and supply

\section{IMPACT ON TRAVEL SERVICES}

There will be economic impact on travel services, most of the airlines at risk from the EU travel ban. The total number of seats on flights scheduled between EU and non-EU countries in a period of 30 days are shown in the table 2.1 below, 
Table 2.1 Total Number of Seats on Flights Scheduled

\begin{tabular}{lll}
\hline No & Flights & Number of seats(1000) \\
\hline 1 & Air France & 815 \\
\hline 2 & Lufthansa & 573 \\
\hline 3 & Emirates & 544 \\
\hline 4 & KLM & 507 \\
\hline 5 & Wiz air & 468 \\
\hline 7 & Qatar airline & 372 \\
\hline 8 & Ryan air & 369 \\
\hline 9 & Turkish airline & 354 \\
\hline 10 & Delta airline & 338 \\
\hline https://voxeu.org/article/economic-impact-pandemic-igm-forum-survey (12th March)
\end{tabular}

\section{IMPACT ON DURABLE EXPENDITURE}

Durable expenditures in face of negative income shocks, one of the strongest response are household with higher demand for cars or vehicles is prosponded. Increase in uncertainty is most likely to have similar effect is the moves by most individuals to spend with precaution the little available resources. There are evidences from project funded by ERC grants: (Surico, P., \& Galeotti, A. 2020).

\section{IMPACT ON SUPPLY CHAIN}

Table 2.2 Shipment and supply of smart

\begin{tabular}{llll}
\hline No & Quarterly & $\begin{array}{l}\text { Forecast } \\
\text { Before The } \\
\text { Outbreak }\end{array}$ & $\begin{array}{l}\text { Forecast With } \\
\text { The Effect Of } \\
\text { The Outbreak }\end{array}$ \\
\hline 1 & Q1 & $60 \mathrm{~m}$ & $78 \mathrm{~m}$ \\
\hline 2 & Q2 & $90 \mathrm{~m}$ & $93 \mathrm{~m}$ \\
\hline 3 & Q3 & $102 \mathrm{~m}$ & $104 \mathrm{~m}$ \\
\hline 4 & Q4 & $108 \mathrm{~m}$ & $110 \mathrm{~m}$ \\
\hline
\end{tabular}

Most sectors that will be affected all of this sectors, all the sectors will have impact with the severity of the pandemic are summarized in the table 2.2 the preliminary views is based on the base case which is sure subject to changes as the COVID-19 outbreak evolves, this is summarized and presented in table 2.3 presented below,

Table 2.3 sectors affected by covid-19

\begin{tabular}{llll}
\hline No & $\begin{array}{l}\text { Estimated degree } \\
\text { of impact in } \\
\text { terms of duration } \\
\text { ( shortest to } \\
\text { longest) }\end{array}$ & $\begin{array}{l}\text { Estimated } \\
\text { global restart } \\
\text { global } \\
\text { slowdown) }\end{array}$ & $\begin{array}{l}\text { Subject change as a result of } \\
\text { covid-19 }\end{array}$ \\
\hline 1 & Q2 & \\
ponsumer & $\begin{array}{l}\text { Overall moderate decline(in } \\
\text { private consumption and export } \\
\text { services) }\end{array}$ \\
\hline & $\begin{array}{l}\text { Demand for certain products } \\
\text { (food and household essentials) }\end{array}$ \\
\hline & $\begin{array}{l}\text { Potential of localized impact } \\
\text { containing negative demand }\end{array}$ \\
\hline
\end{tabular}




\begin{tabular}{|c|c|c|c|}
\hline \multirow[t]{2}{*}{2} & \multirow[t]{2}{*}{ automotive } & \multirow[t]{2}{*}{ Q2/Q3 } & $\begin{array}{l}\text { Existing vulnerabilities(decline } \\
\text { in sales) brought about by } \\
\text { decline in Chinese demand, } \\
\text { continued supply chin and } \\
\text { product distribution in } \\
\text { countries like chine ASIA and } \\
\text { EU }\end{array}$ \\
\hline & & & $\begin{array}{l}\text { headwinds may persist to Q3 } \\
\text { given tight interventions less } \\
\text { than six(6) weeks supply chain } \\
\text { complexity with minimal } \\
\text { ability to shift }\end{array}$ \\
\hline \multirow[t]{2}{*}{3} & \multirow[t]{2}{*}{ Oil and gas } & \multirow[t]{2}{*}{ Q3 } & $\begin{array}{l}\text { oil price decline as a result of } \\
\text { longer term demand impact and } \\
\text { short-term supply overhang }\end{array}$ \\
\hline & & & $\begin{array}{l}\text { With resumption of consumer } \\
\text { demand there will be rebound } \\
\text { but long-term impact is likely if } \\
\text { situation persist and depresses } \\
\text { price beyond a year }\end{array}$ \\
\hline \multirow[t]{2}{*}{4} & \multirow[t]{2}{*}{ Aviationlairlines } & \multirow[t]{2}{*}{ Q3/early Q4 } & $\begin{array}{l}\text { Sustained headwinds with the } \\
\text { global travel acutely impacted. } \\
\text { Summer season is sure missed, } \\
\text { there will be forward booking } \\
\text { for march-April down } \\
\text { significantly reports will be for } \\
\text { over } 40 \% \text { in certain airlines. }\end{array}$ \\
\hline & & & $\begin{array}{l}\text { Pace will recover faster for } \\
\text { domestic travels and slower } \\
\text { pace recovery for long-haul } \\
\text { and/or international travel up to } \\
\text { 3-4quarters }\end{array}$ \\
\hline \multirow[t]{3}{*}{5} & \multirow[t]{3}{*}{$\begin{array}{l}\text { Tourism and } \\
\text { hospitality }\end{array}$} & \multirow[t]{3}{*}{ Q4 } & $\begin{array}{l}\text { Sever ripple effects such as } \\
\text { closure in Paris tourism down } \\
50 \% \text { in Vietnam despite the } \\
\text { lack of local transmission. }\end{array}$ \\
\hline & & & $\begin{array}{l}\text { Delay in recovery until winter } \\
\text { season when the disease might } \\
\text { surge again. }\end{array}$ \\
\hline & & & $\begin{array}{l}\text { Potential of more localized } \\
\text { impact containing negative hit } \\
\text { in demand }\end{array}$ \\
\hline
\end{tabular}

\section{SOCIAL ISOLATION}

Social isolation increased as a result of isolation during the quarantine or social distancing phase will be costly across demographics, especially the elderly, whose families are more likely to distance from them for fear of spreading the viruses. This older population are both vulnerable to the virus since there immune system has been compromised. 


\section{HIGHER SKILLED WORKERS}

High skilled workers are likely to work from home, a lot of firms may consider and increase acceptance of remote work as an improvement with more flexibility for workers, less congestions in cities, unequal opportunities. Some of the high-skilled can work from home such as financial services, corporate jobs education but not health professionals. The lower skilled workers such as drivers, deliverers, cleaners, supply chain distributors, retail workers and so on. Skills may correlate with liquidity to sustain brief unemployment during this health crisis (Khan, N., \& Faisal, S. 2020)

High level earners are more likely to work from home, this will imply $29 \%$ of American workers can work from home according to BLS survey in 2017 -2018. The proportion of such individuals vary widely across occupations and industries. Income is also a crucial factor in working from home as shown in table 2.4

Table 2.4 Proportion of Workers Working From Home

\begin{tabular}{lll}
\hline No & Range & Percentages \\
\hline 1 & $0-25^{\text {th }}$ percentile & $9.2 \%$ \\
\hline 2 & $25-50^{\text {th }}$ percentile & $20.1 \%$ \\
\hline 3 & $50-75^{\text {th }}$ percentile & $37.3 \%$ \\
\hline 4 & $75-100^{\text {th }}$ percentile & $61.5 \%$ \\
\hline
\end{tabular}

Source: https://www.bls.gov/news.release/flex2.t01.htm

There are strong similarity across sectors, a lot of workers in the manufacturing, retail, leisure, construction, tourism, transportation, education and utilities can hardly work from. There will be potential long time changes

\section{POTENTIAL LONG TIME CHANGES}

Most universities and business world have quietly shifted towards remote working and learning for the rest of the school year, the situation is favorable or can be managed by them. Despite the disruption, this event occurrence is seen as a critical opportunity for digital learning a lot of companies are hoping this can be a persistent change. Looking at a popular remote conferencing software, it has shown a sharp increase in its stock price during the first few months of 2020 (Baldwin, R., \& di Mauro, B. W. 2020).

\section{HOME SCHOOLING INTERNET ACCESS AND EDUCATION}

A lot of learners more than 770million are now affected by the school closure. With the schools closures home-schooling and online tutorials is being encouraged. There are some empirical studies that shows the strong impact of quality of parental education on pupils educational attainment and long-term outcomes (Heckman, 2006) thus school closure will reinforce this inequality. There are universally access to online resources between 50 million and 80 million people in china alone are reported to have no sufficient internet connection or web-enable device as at 2018 (Josephine Wolff, 2020) 10\% of household in the United Kingdom do not have internet connection. The closure will be reason to disproportionately affect children from low-income families or poor families, many of whom receives daily breakfast and lunch and in some cases dinner on campus (Howard Blume, 2020).

\section{FEEDBACK LOOP INTO DEMAND}

The race between demand and supply at the beginning of the outbreak of covid-19 may look like supply shock. There is disruption in supply chain globally, social distancing and quarantine worldwide decreasing the supply for labor. The great recession of 2007 originated 
as supply shock in the financial sector, war and natural disaster with origin of supply shock is the destruction of infrastructure or large scale loss in labor force permanently (Baldwin, R \& B Weder di Mauro, 2020).

Demand will affect materialization, uncertain about the progression of the disease, uncertain about new economy policies that may come up, non-permanent worker losing their job and hence no income, particularly in affected industries such as manufacturing and hospitality. Increase in savings by household as a precaution for uncertainties until situation is clear.

\section{FEEDBACK LOOP INTO SUPPLY}

This will imply firms such as firms more dependent on cash flows, lack liquidity to fulfill commitments while facing a decline in demand and hence forces to file for bankruptcies. The demand and supply loop similarly to financial crisis, through all uncertainties about the pandemic. This is different from war or disaster where demand might increase as government redirect efforts towards rebuilding or fighting and hence potentially inflationary (BénassyQuéré, A., et.al 2020)

The race between the demand and supply feedback loop into demand. Workers losing their jobs from business closure do not have any sources of income and hence will have to lower consumption, finally depressing aggregated demand. Baldwin, R., \& di Mauro, B. W. 2020 reported IGM poll of top economists suggested that the impact of this demand stock will be larger than supply presented table 2.5

Table 2.5 IGM poll suggestions

\begin{tabular}{llll}
\hline No & Views & $\begin{array}{l}\text { European } \\
\text { panel } \\
\text { views }\end{array}$ & $\begin{array}{l}\text { US panel } \\
\text { views }\end{array}$ \\
\hline 1 & Strongly agree & $4 \%$ & $0 \%$ \\
\hline 2 & Agree & $43 \%$ & $44 \%$ \\
\hline 3 & Uncertain & $41 \%$ & $52 \%$ \\
\hline 5 & Disagree & $12 \%$ & $3 \%$ \\
\hline
\end{tabular}

Source: https://voxeu.org/article/economic-impact-pandemic-igm-forum-survey

\section{MANY SMALL BUSINESS DEPENDING ON CASH FLOW}

Small businesses depending on cash flow to asset ratio above 0.5 account for about $10 \%$ of employment in private businesses. All the private businesses account for more than $60 \%$ of the total employment. Hence small firms with cash flow assets greater than 0.5 account for some $6 \%$ of the total employment in every economy from calculations from (Surico, P., \& Galeotti, A. 2020).

\section{CONCLUSIONS}

Global recession seems inevitable, there is also possibility of emerging markets. The overall demand effect is probably higher than the initial supply shock. There will be uncertainties, panic, a lot of panic buying and lock-down policies is a key to drive large drop in demand. The investment in a lot of firms especially the small and young firms, spending for households such as rent and mortgators depend largely on cash flow. Large drop in demand will lead to force closure in a lot of firms and this will lead to an increase in lay-offs and hence further drop in consumption, and sadly the economy leads to depressing loop. 


\section{REFERENCES}

Baldwin, R., \& di Mauro, B. W. (2020). Economics in the Time of COVID-19. A VoxEU. org Book, Centre for Economic Policy Research, London. Accessed, 26.

Baldwin, R. E., \& di Mauro, W. (2020). Mitigating the COVID economic crisis (No. BOOK). for Economic Policy Research.

Bénassy-Quéré, A., Marimon, R., Pisani-Ferry, J., Reichlin, L., Schoenmaker, D., \& Weder, B. 2020). 13 COVID-19: Europe needs a catastrophe relief plan. Mitigating the COVID Economic Crisis: Act Fast and Do Whatever, 121.

Howard Blume (2020, march 27). With all the distractions at home, low-income students need Headphones to study Los Angeles times. Retrieved from https://www.latimes.com/california/story/2020-03-27/low-income-students-inchoatic-homes-need-headphones-during-school-closure.

Josephine Wolff (2020, March 17) Our Internet Isn't Ready for Coronavirus._The New York Times, from https://www.nytimes.com/2020/03/17/opinion/coronavirus-broadband-internetwork-from-home.html

Khan, N., \& Faisal, S. (2020). Epidemiology of Corona Virus in the World and Its Effects on the China Economy. Available at SSRN 3548292.

Surico, P., \& Galeotti, A. (2020). The economics of a pandemic: the case of Covid19. Wheeler Institute for Business and Development, LBS. London: London Business School.

World Health Organization. (2020). Novel Coronavirus ( 2019-nCoV): situation report, 33. Retrieved from https://www.who.int/docs/defaultsource/coronaviruse/situation-reports/20200129-sitrep-9-ncov.pdf

World Health Organization. (2020). Novel Coronavirus ( 2019-nCoV): situation report, 78. Retrieved from https://www.who.int/emergencies/diseases/novelcoronavirus-2019/situation-reports 